\title{
Rapid Tube Hydroforming - The Innovative Casting-Forming Method for Rapid Prototyping
}

Andrzej Kochański, Hanna Sadłowska

Warsaw University of Technology, Institute of Manufacturing Technologies, Narbutta 85, 02-524 Warsaw, Poland. E-mail: akochans@wip.pw.edu.pl

In the recent years, the demand for weight reduction in modern vehicle construction has led to an increase in the application of hydroforming processes for production of automotive and aerospace lightweight components. The tube hydroforming measurement site (TH stand), designed and built at Warsaw University of Technology allows both die, and free tube hydroforming processes to be performed, thereby making it possible to obtain information about the material, as well as optimal process parameters [1] [2]. The present freshly patented method for metal tube hydroforming is dedicated to short product series or even single products and prototypes [3]. The method is applicable to forming difficult-to-machine materials. The well-known techniques use dies made of plastic or wood, especially to form short product series. The use of moulding sand and properly prepared geometry of casting mould makes possible shaping materials at high temperatures, which could not be done in previous short series solutions, where a plastic or wooden die were used.

Keywords: Hydroforming, Casting mould, Rapid prototyping, Process numerical modelling, Mohr-Coulomb

\section{Introduction}

The growing interest in hydroforming as a method of component forming is tightly connected with higher and higher demand for combining the high strength of components with their low weight. This is important in many areas of use, such as the aerospace and automotive industry or the production of bicycle components [3].
One of the limitations of hydroforming was forming in short series. A consequence of a high die cost was that hydroforming was economically justified for series of 1000 pieces [4]. The introduction of plastic or even hardwood dies, which are cheaper and easier to prepare, made hydroforming economically justified for shorter series, even for series of 100 pieces [5]. However, the production of individual exemplars still remained economically unjustified.

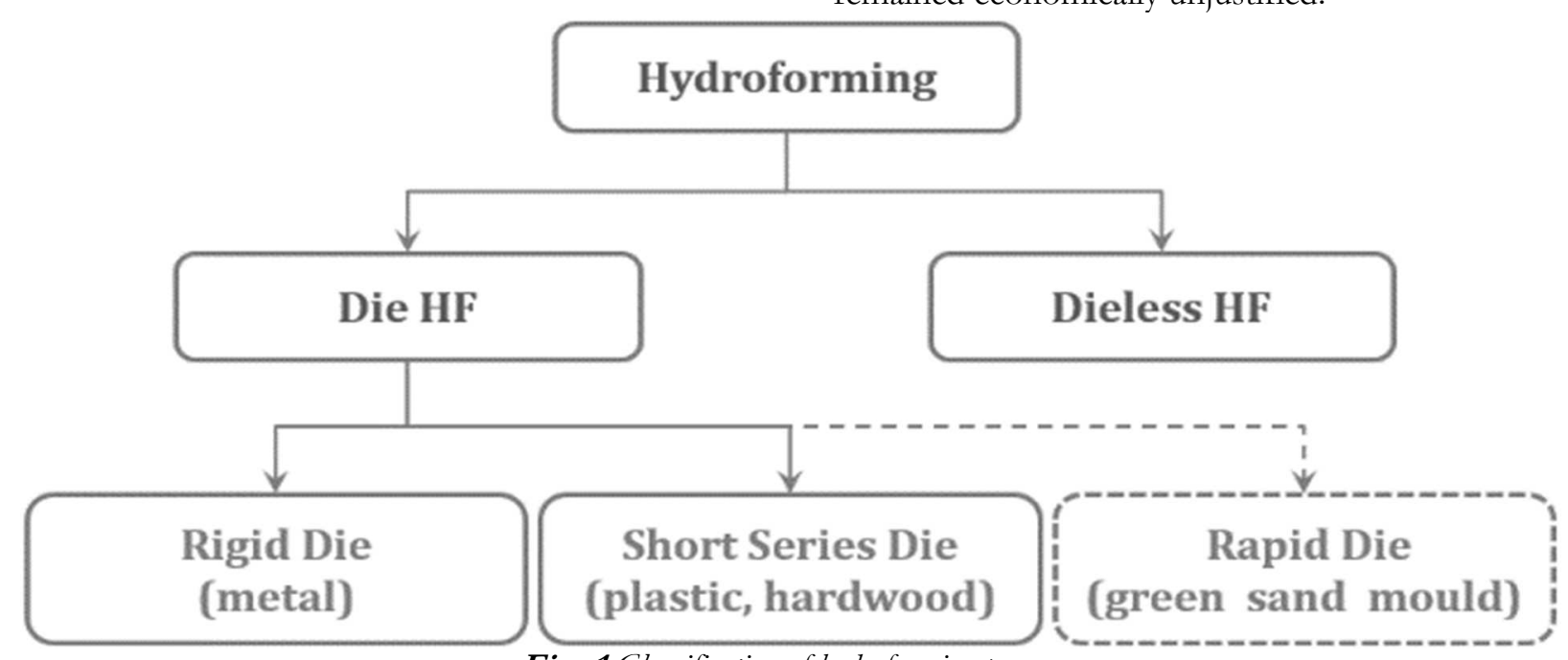

Fig. 1 Classification of bydroforming process

Rapid changes in machines and devices under production, the necessity for prototyping, as well as individual demand have made it a matter of urgent necessity to develop a new technology which would employ hydroforming, but which, at the same time, would make possible the use of a very cheap forming die. To make the die price really low, dies need to be produced in a very simple way and with the use of common and cheap materials. Developing such a method would make it possible, as shown in Fig. 1, to complete the 
hydroforming offer for the whole range of series sizes of components under production and including hydroforming technology in the family of technologies used in Rapid Prototyping, expanding their small number for now [6].

\section{Rapid die hydroforming technology}

The requirements for cheap and easy-to-obtain materials that may be used in the preparation of prototype hydroforming dies are satisfied by foundry moulding sands, for instance by green sands or by moulding sands with water glass. As originally planned, materials used for foundry moulding sands are cheap, easy to obtain, and in the case of green sands, suitable for being reused. In the process of profile forming, a die made of moulding materials gives in to pressure and does not stick to the stable, unchanging shape of the die cavity. The main point of the proposed technological solution is to set the original shape of the die cavity in the function of the properties of the moulding sand used for the making of the die, as well as the properties of the profile under forming. The original shape of the die cavity is selected in numerical modelling.

Fig. 2 schematically represents the forming mechanism proposed in the PL424401 patent [7]. The expanding profile in the die cavity increases its volume and thereby displaces the moulding sand, which brings about its quick local compacting. The moulding sand, which gets compacted in selected places, makes more difficult and finally stops the process of profile expansion. At the same time, in those areas in which the profile has not come into contact with the moulding sand of the die or in which the moulding sand has got only partially compacted, the profile undergoes free forming. Stopping the expansion in selected areas, with the simultaneous free or semi-free shaping in other areas makes possible obtaining the designed shape.

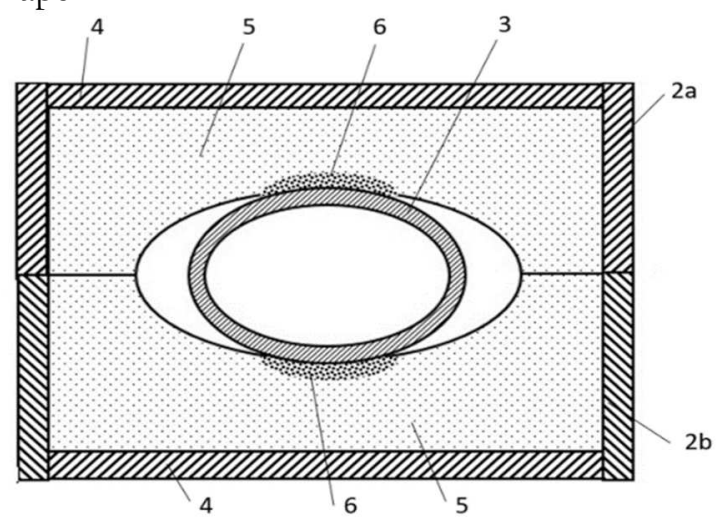

Fig. $2 A$ cross-section of the die together with the profile under forming - the schematic forming mechanism [7]

It is also numerical modelling which is used for predicting the outcome of and for controlling the process of deforming the matrix die taking place during profile expansion, as well as for establishing the ultimate shape of the profile. The ultimate shape of the profile depends on the properties of the material from which the profile is made, its original geometry, as well as the properties of the moulding sand out of which the matrix has been made and the boundary conditions (for instance, the friction between the moulding sand and the profile under forming).

As has been demonstrated, for instance, in [8], it is the Mohr-Coulomb model which is standardly used for the initial calculations in the numerical modelling of moulding sands in the compacting process. For moulding sands and loose materials the cohesion coefficient $\mathrm{c}$ and the internal friction angle $\Phi$, which are the critical values for the $\mathrm{M}-\mathrm{C}$ model, assume the values within the following ranges: $\mathrm{c}=0.1 \div 5.0 \mathrm{MPa}$, and $\Phi=10^{\circ} \div 50^{\circ}[9]$.

A change in those two properties makes it possible to exert considerable influence on the way in which the profile is being formed. Fig. 3 shows examples of modelling results for a moulding sand with two different values of the cohesion coefficient $\mathrm{c}$ and the internal friction angle $\Phi$. Fig. 3a represents the simulation results for the sand with the cohesion coefficient $\mathrm{c}=$ 1.5 and the internal friction angle $\Phi=40^{\circ}$, while Fig. $3 \mathrm{~b}-$ for $\mathrm{c}=0.1$ and $\Phi=10^{\circ}$. Fig. $3 \mathrm{~b}$ shows considerably bigger moulding sand displacement brought about by its being compacted by the profile under forming.

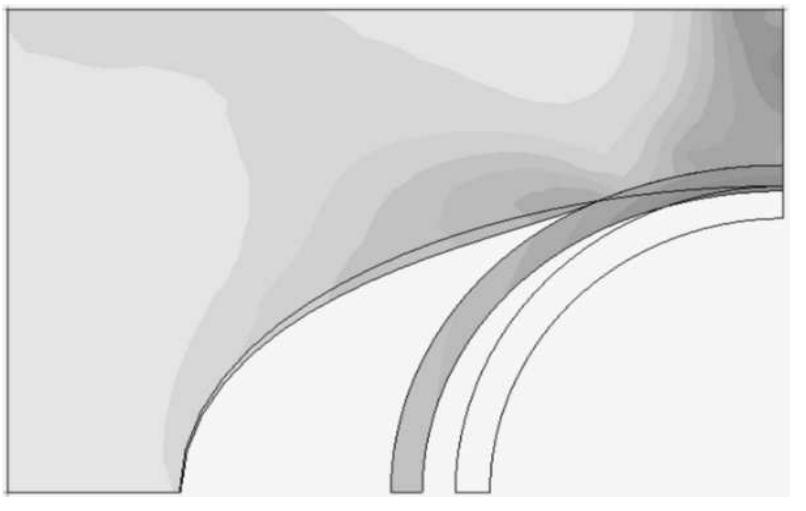

a)

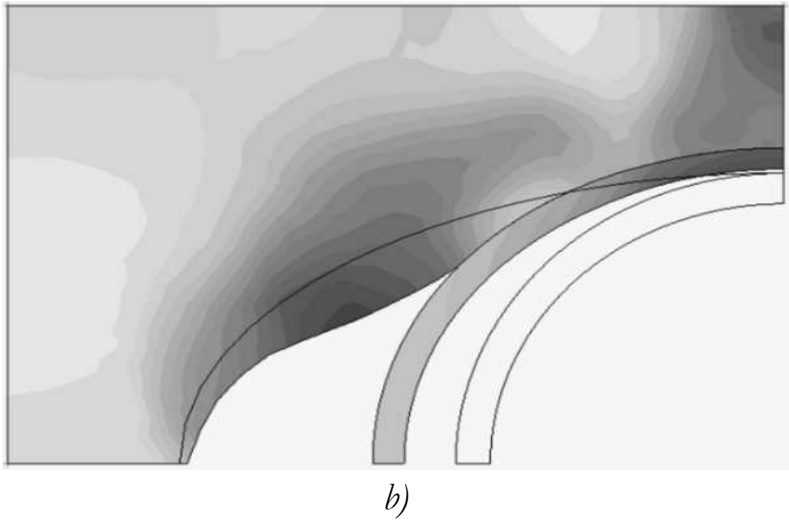

Fig. 3 An example of forming a profile with an elliptical cross-section in two kinds of moulding sand: a) $c=1.5, \Phi=$ $40^{\circ}$, b) $c=0.1$ and $\Phi=10^{\circ}$ 
The proposed technology using moulding sands minimizes certain limitations on the forming conditions in prototype production, such as, for instance the value of the maximal pressure of the working liquid or the profile forming temperature. Thanks to this, the method may be used for forming profiles made of advanced materials, such as high-strength steels, for instance of the AHSS type, without any limitations following from the strength of dies dedicated to short series forming, for instance plastic dies.

\section{Experimental results}

Experimental studies were conducted with the use of the hydroforming stand HF at the Department of Metal Forming and Foundry, Warsaw Technical University [10]. A photo of the stand and the initial profile geometry are shown, respectively, in Fig. 4 and Fig. 5. Closed profiles made of seamless were used in the tests due to their homogeneous structure and properties [11].

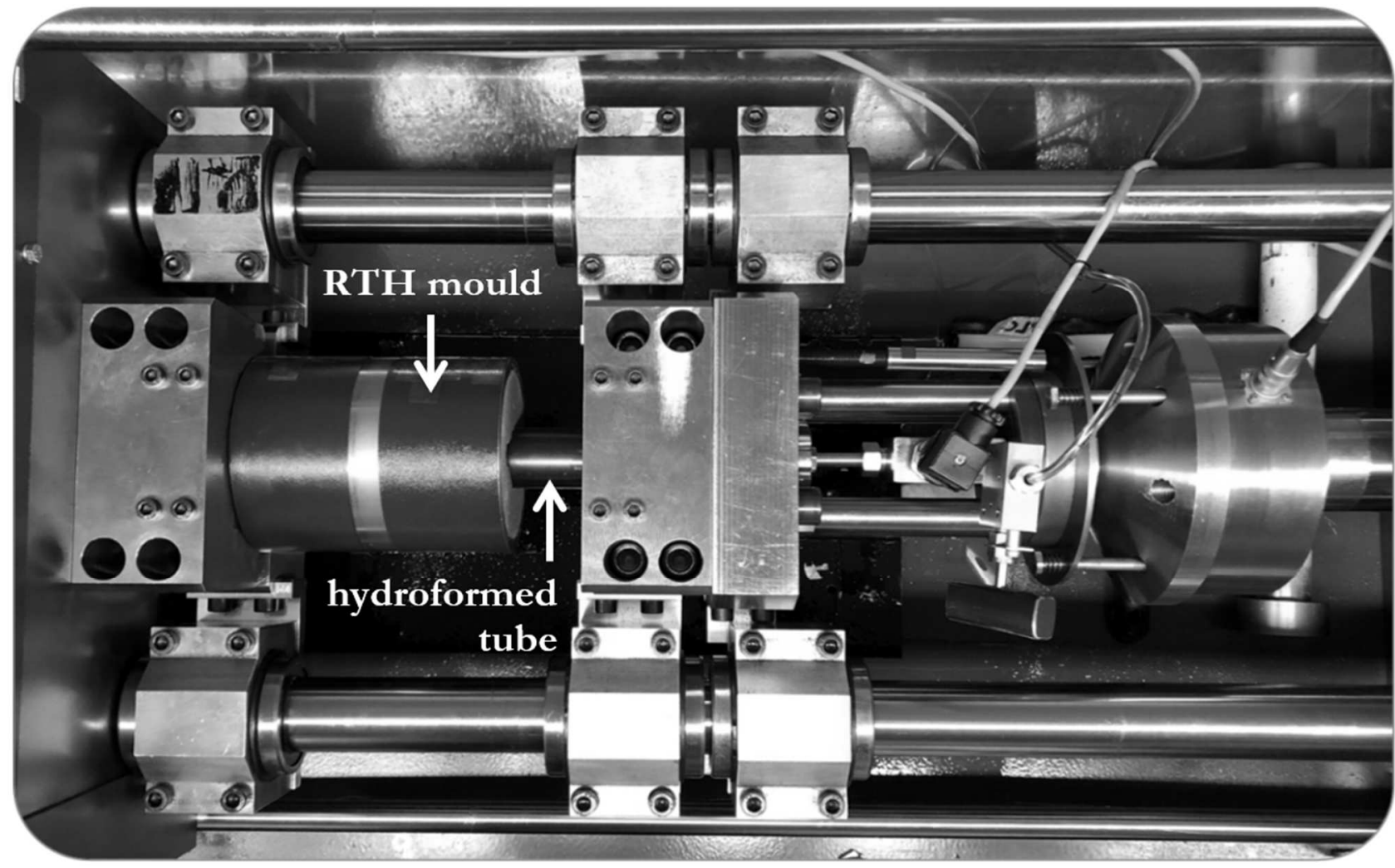

Fig. 4 The test stand with the installed die made of a moulding sand with water glass

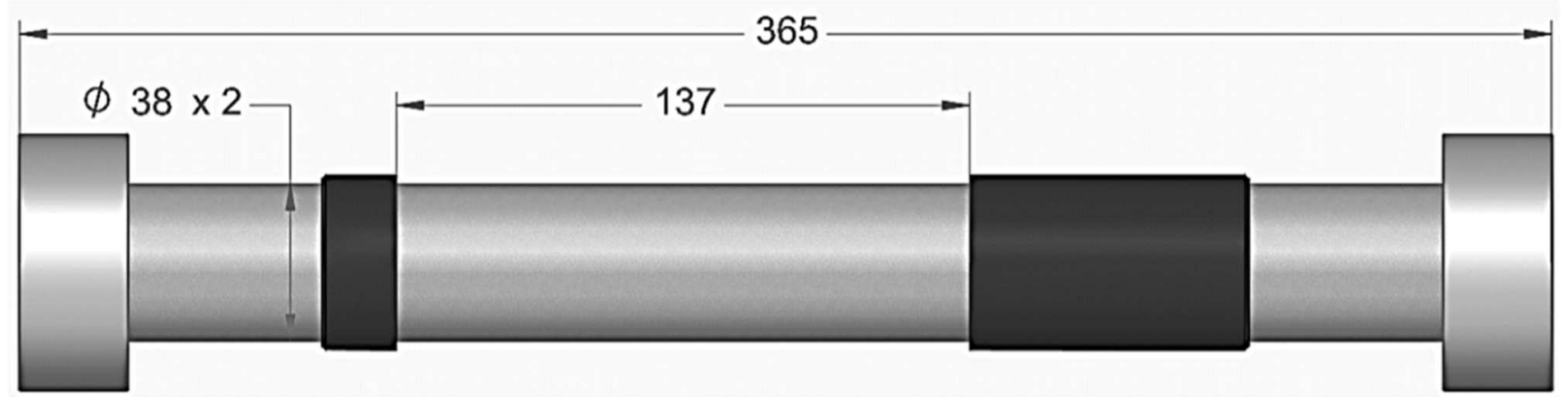

Fig. 5 The initial profile geometry - RTH tube specimen: $38 \times 2$ seamless tube (material: normalized steel E235)

In the initial experimental studies moulding sand with water glass was used. The composition of the moulding sand out of which the die was made is represented in Tab. 1.

Tab. 1 The composition of the moulding sand with water glass

\begin{tabular}{|l|l|l|}
\hline Moulding sand component & Percentage \\
\hline Sand: Grudzeń Las 0.32/0.40/0.20 & $100 \%$ & sand matrix \\
\hline Sodium water glass R-145 & $7 \%$ & relative to sand matrix \\
\hline Ester hardener (of ethylene glycol diacetate) Flodur FM-4 & $14 \%$ & relative to water glass \\
\hline
\end{tabular}


Standard specimens were made out of the prepared moulding sand for compressive strength tests (a cylindrical specimen $\Phi=50 \mathrm{~mm}, \mathrm{~h}=50 \mathrm{~mm}$ ). The specimens were made in the laboratory rammer LUA-2e. 3 hours after forming the moulding sand exhibited the mean compressive strength of $\mathrm{R}_{\mathrm{m}}=2 \mathrm{MPa}$, and after 5 days $R_{m}=5 \mathrm{MPa}$. Two dies (with two cavity geometries) were made out of the prepared moulding sand they are represented in Fig. 6.

\section{R'TH mould}

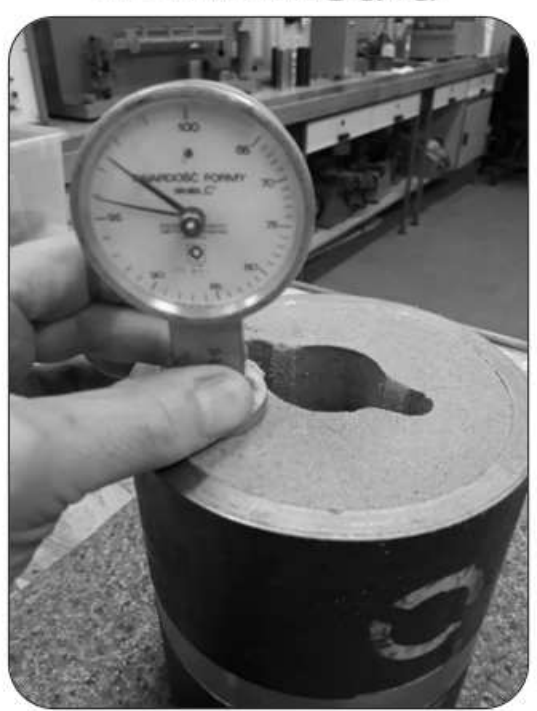

Type A

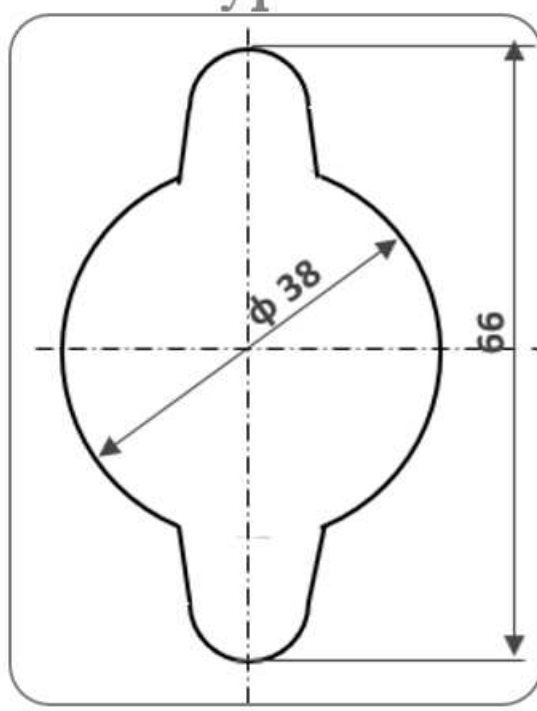

Type B

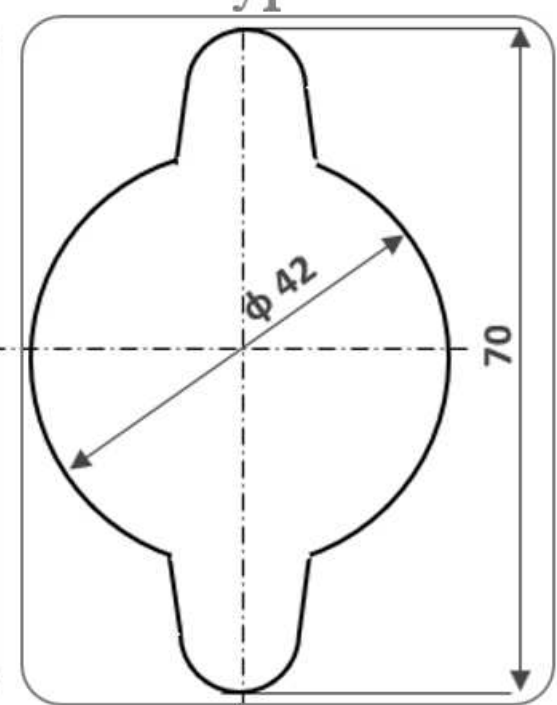

Fig. 6 A die made of moulding sand with water glass and the diagrams representing the two cavity geometries

The original shape of the die followed from the assumption that the profile under forming would be in contact with the moulding mass from the very beginning - thus, the original cavity diameter equalled the outside diameter of the profile under forming. However, it turned out that the friction force following from the moulding sand-profile friction coefficient is so big that it hinders the displacement of the profile material along the axis, thereby making impossible the feeding of the profile under forming in its thinned areas. In the case of the alternative geometry the contact between the moulding sand and the profile occurred at a later stage of forming, which made possible considerable profile deformation. Fig. 7a shows the profile subjected to forming in the type B die, while Fig. $7 \mathrm{~b}$ represents the profile obtained as a result of forming, as well the cross-section geometry in the central part of the profile under forming.

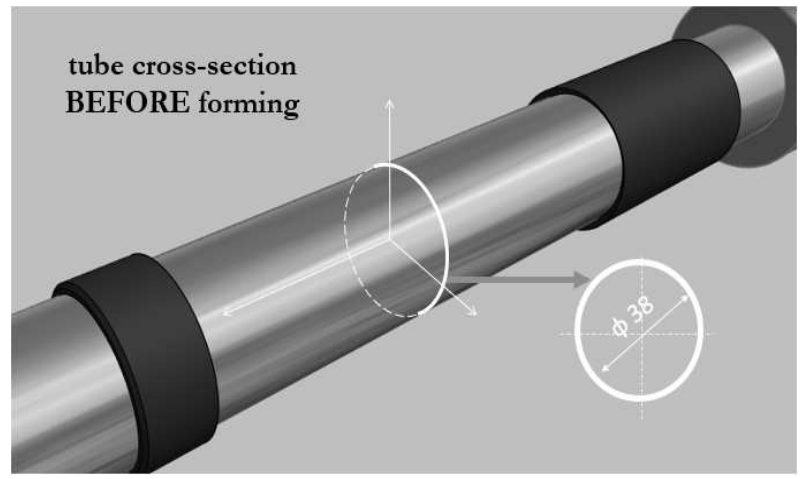

a)

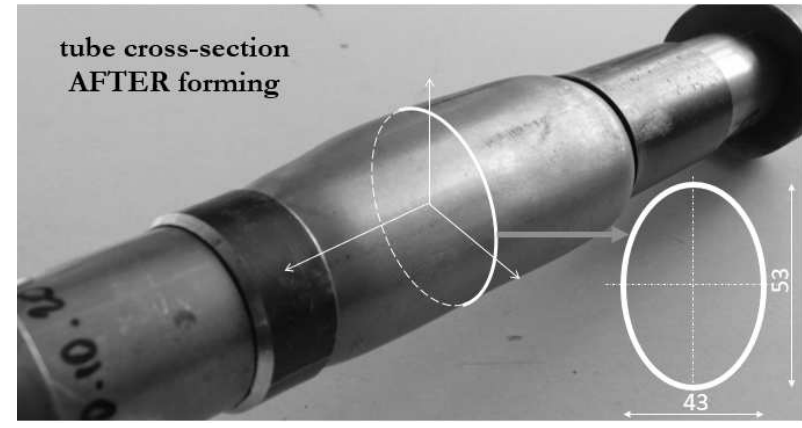

b)

Fig. 7 The dimensions of the cross section of the profile under forming: a) initial geometry - diameter Ø38 mm, b) after forming - elliptical cross-section

The obtained profile shape clearly demonstrates the influence of the die cavity geometry on the profile under forming. In the process of forming profile deformation was limited in the area of contact between the profile and the moulding sand, and at the same time the deformation was considerably bigger in the area with no contact between the profile and the die cavity. As a result of forming a profile with the initial circular cross-section of the $38 \mathrm{~mm}$ diameter, what was obtained was a profile with the elliptical crosssection with the diameters of $43 \mathrm{~mm}$ and $53 \mathrm{~mm}$.

As demonstrated in numerical modelling (Fig 3a, b), the properties of the moulding sand exert decisive influence on the area of contact between the profile under forming and the die cavity. 


\section{Summary}

The initial experimental tests demonstrated the viability of the proposed new method for obtaining diverse profile shapes, including profiles with an elliptical cross-section involving a considerable difference between the two diameters. Numerical modelling demonstrated considerable influence on the profile under forming of such moulding sand parameters as the cohesion coefficient $\mathrm{c}$ or the internal friction angle $\Phi$.

The possibility of obtaining considerable deformations is directly dependent on the profile material's capability of getting displaced into the deformation area. An increase in the diameters (of an ellipsis) is connected with the longitudinal displacement of the profile material. Material displacement is hindered by the force of friction between the moulding sand and the profile under forming. This creates the necessity of 3D numerical modelling with the aim of the model's taking into consideration the moulding sand displacement along the longitudinal axis of the profiles, and not only its compacting which is transverse relative to the profile's axis.

\section{References}

[1] SADŁOWSKA H., JASIŃSKI C., MORAWIŃSKI Ł., (2020), Strain measurements on the tube hydroforming testing machine, In: Archives of Metals and Metallurgy, Vol. 65 , Iss. 1, pp. 257-263

[2] SADEOWSKA H., (2015), Odkształcanie się rur podczas swobodnego rozpęczania hydromechanicznego na stanowisku TH, In: Prace Nankowe Politechniki Warszawskiej. Mechanika, Vol. 267, pp. 25-30 (in Polish)

[3] KOCAŃDA A., SADLOWSKA H., (2008), Automotive component development by means of hydroforming: A review, In: Archives of Civil and Mechanical Engineering, Vol. 8(3), DOI: 10.1016/S1644-9665(12)60163-0

[4] PERZYK M., (1997), Wybór procesu technologicznego w budowie massyn, In: Oficyna Wydawnicza Politechniki Warszawskiej, (in Polish)
[5] PINTO, M., SANTOS, A., TEIXEIRA, P., BOLT, P. (2008). Study on the usability and robustness of polymer and wood materials for tooling in sheet metal forming. In: Journal of Materials Processing Tech, Vol. 202(1-3), pp. 4753.

[6] KELLNER T., KYNCL J., PITRMUC Z., BERANEK L., KANAK M., KYNCL M., (2019), Production Process Planning in Additive Manufacturing and Conventional Machining Technology Manufacturing System, In: Manufacturing Technology, Vol. 19, No. 2, pp. 232-237,

DOI: 10.21062/ujep/275.2019/a/12132489/MT/19/2/232

[7] KOCHAŃSKI A., SADŁOWSKA H., (2019), Patent No. PL424401, In: Bulletin of the Patent Office of Inventions and Utility Models, Vol. 17, pp. 11

[8] BAST J., KADAUW A., MALASCHKIN A., (2009), Optimising of Moulding Parameters for Green Sand Compaction by Computer Simulation and a New Compaction Measuring Device, In: International Journal of Metalcasting, 3.2, pp.55-65.

[9] WASZKIEWICZ S., (1992), Wplyw błedów odwzorowania wneki formy na doktadność wymiarowa odlewón, Warszawa, In: Prace Naukowe. Politechnika Warszawska. Mechanika, Vol. 147 (in Polish)

[10] SADLOWSKA H., (2013), Kształtowanie hydromechaniczne rur na stanowisku badawczym TH, In: Prace Nankowe. Politechnika Warszanska. Mechanika, Fizyczne $i$ matematyczne modelowanie procesón obróbki plastycznej, Vol.:235, pp. 69 (in Polish), ISSN 0137-2335

[11] KEJZLA P., SEIBERT O., ANDRSOVA Z., BURIK P. (2018). The Study of the Effect of Mechanical and Heat Treatment on the Crystal Texture of Cold Drawn Seamless Tubes, In: Manufacturing Technology, Vol. 18, No. 4, pp. 585592, DOI: $10.21062 /$ ujep/142.2018/a/12132489/MT/18/4/585 